\title{
Connectance of species interaction networks and conservation value: Is it any good to be well connected?
}

\author{
Ruben Heleno ${ }^{\mathrm{a}, *}$, Mariano Devoto ${ }^{\mathrm{b}}$, Michael Pocock $^{\mathrm{c}}$ \\ a Mediterranean Institute of Advanced Studies (CSIC-UIB), c/ Miquel Marqués 21, 07190 Esporles, Mallorca, Balearic Islands, Spain

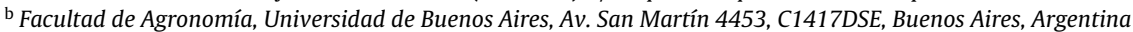 \\ ' School of Biological Sciences, University of Bristol, Bristol BS8 1UG, United Kingdom
}

\section{A R T I C L E I N F O}

\section{Article history:}

Received 11 February 2011

Received in revised form 6 May 2011

Accepted 28 June 2011

\section{Keywords:}

Community

Complexity

Food web

Rare species

Stability

\begin{abstract}
A B S T R A C T
Recently, the focus of conservation efforts gradually changed from a species-centred approach to a broader ambition of conserving functional ecosystems. This new approach relies on the understanding that much ecosystem function is a result of the interaction of species to form complex interaction networks. Therefore measures summarising holistic attributes of such ecological networks have the potential to provide useful indicators to guide and assess conservation objectives. The most generally accepted insight is that complexity in species interactions, measured by network connectance, is an important attribute of healthy communities which usually protects them from secondary extinctions. An implicit and overlooked corollary to this generalization is that conservation efforts should be directed to conserve highly connected communities. We conducted a literature review to search for empirical evidence of a relationship between connectance (complexity) and conservation value (communities on different stages of degradation). Our results show that the often assumed positive relationship between highly connected and desirable (i.e. with high conservation value) communities does not derive from empirical data and that the topic deserves further discussion. Given the conflicting empirical evidence revealed in this study, it is clear that connectance on its own cannot provide clear information about conservation value. In the face of the ongoing biodiversity crisis, studies of species interaction networks should incorporate the different 'conservation value' of nodes (i.e. species) in a network if it is to be of practical use in guiding and evaluating conservation practice.
\end{abstract}

(c) 2011 Elsevier Ltd. All rights reserved.

\section{Introduction}

In recent decades the focus of conservation has gradually changed from a species-centred approach into protecting ecosystem functions and their impact on human wellbeing through the provision of ecosystem services (Millennium Ecosystem Assessment, 2005). Intrinsic to this approach is the understanding that much ecosystem function is a result of the interaction of species with each other (Duffy et al., 2007). Not only does human welfare depends on species interactions, but it is through interactions that disturbance can cascade through whole communities. The structure of ecological networks can therefore influence the resilience and robustness of ecosystems (Dunne et al., 2002; Thébault and Fontaine, 2010). In order to conserve ecosystem function, it is important that these species interaction networks are robust to cascading species loss, and it has been suggested that highly connected networks are at earlier stages of ecological

\footnotetext{
* Corresponding author. Tel.: +351963645965.

E-mail address: ruben_huttel@hotmail.com (R. Heleno).
}

degradation and better prepared against it (Gilbert, 2009). But what does this mean, in practice, for the conservation of species and habitats? Can the connectance of these species interaction networks give an indication of their conservation value?

Species interaction networks depict groups of species that interact with each other, and these interactions can be trophic, as in food-webs, or mutualistic, such as pollination and seed dispersal networks. Framing important conservations problems into this community-oriented viewpoint has been argued to be a powerful tool in order to direct conservation planning, particularly when this seeks to conserve ecosystem function (Heleno et al., 2010).

One of the earliest and most popular metrics proposed to characterise species interaction networks is "connectance": the proportion of realized interactions from the pool of all possible interactions between the species of a network (May, 1973). Connectance was central to the initial "complexity begets stability" debate (May, 1973, 1999; Pimm, 1984) and despite considerable criticism, continues to be broadly used as a measure of community complexity (Banasek-Richter et al., 2009; Gilbert, 2009; Tylianakis et al., 2010). There are several caveats regarding the use 
Table 1

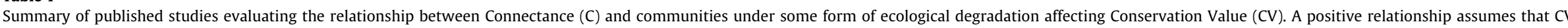

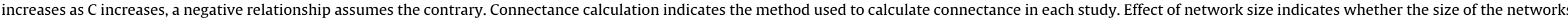
was considered when comparing connectance values between communities. Question marks highlight data that are not unequivoca.

\begin{tabular}{|c|c|c|c|c|c|c|c|}
\hline System & $\begin{array}{l}\text { Ecological correlate of } \\
\text { degradation }\end{array}$ & $\begin{array}{l}\text { Expected relation } \\
\text { of } \mathrm{C} \text { and } \mathrm{CV}\end{array}$ & Result & $\begin{array}{l}\text { Relationship of C } \\
\text { and CV }\end{array}$ & $\begin{array}{l}\text { Connectance } \\
\text { calculation }\end{array}$ & $\begin{array}{l}\text { Effect of network } \\
\text { size }\end{array}$ & Reference \\
\hline $\begin{array}{l}40 \text { published food webs (marine, estuarine, } \\
\text { terrestrial) }\end{array}$ & Disturbance & No expectation & $\begin{array}{l}\text { C lower on } \\
\text { disturbed }\end{array}$ & Positive & Qualitative & Yes & Briand (1983) \\
\hline Zooplankton food webs on lakes & Acidification & Positive & C lower on acidic & Positive & Qualitative & No & $\begin{array}{l}\text { Locke and Sprules } \\
\text { (1994) }\end{array}$ \\
\hline Periphyton-macroinvertebrates on stream & Invasion by crayfish & No expectation & $\begin{array}{l}\text { C higher on } \\
\text { invaded }\end{array}$ & Negative & Qualitative (?) & No & $\begin{array}{l}\text { Charlebois and } \\
\text { Lamberti (1996) }\end{array}$ \\
\hline Fish-macroinvertebrates-algae on stream & Disturbance & Positive & No effect & None & Qualitative & Yes & $\begin{array}{l}\text { Townsend et al. } \\
\text { (1998) }\end{array}$ \\
\hline Stream food web & Invasion by dragonfly & No expectation & $\begin{array}{l}\text { C higher on } \\
\text { invaded }\end{array}$ & Negative & Qualitative & No & $\begin{array}{l}\text { Woodward and } \\
\text { Hildrew (2001) }\end{array}$ \\
\hline Plant-pollinator (visitation networks) & Alien vs native plants & No expectation & C lower on aliens & Positive & Qualitative & Yes & $\begin{array}{l}\text { Memmott and } \\
\text { Waser (2002) }\end{array}$ \\
\hline Zooplankton-copepods on ponds & Insecticide application & Positive & C lower on sprayed & Positive & Qualitative & No & $\begin{array}{l}\text { Kreutzweiser et al. } \\
(2004)\end{array}$ \\
\hline Crustacean zooplankton-copepods on ponds & Insecticide application & Positive & $\begin{array}{l}\text { C higher on } \\
\text { sprayed }\end{array}$ & Negative & Qualitative & No & $\begin{array}{l}\text { Kreutzweiser and } \\
\text { Thomas (1995) in } \\
\text { Kreutzweiser et al. } \\
\text { (2004) }\end{array}$ \\
\hline Marine food web & Overfishing & No expectation & $\begin{array}{l}\text { C higher on } \\
\text { overfished }\end{array}$ & Negative & Qualitative (?) & No & $\begin{array}{l}\text { Heymans et al. } \\
(2004)\end{array}$ \\
\hline Plant-pollinators on hay meadows & Restoration & No expectation & $\begin{array}{l}\text { C marginally higher } \\
\text { on old meadows }\end{array}$ & None (?) & Qualitative & No & $\begin{array}{l}\text { Forup and } \\
\text { Memmott (2005) }\end{array}$ \\
\hline $\begin{array}{l}\text { Bees/wasps-parasitoids on agricultural } \\
\text { land-forest gradient }\end{array}$ & Agricultural intensification & No expectation & No effect & None & Quantitative & Yes & $\begin{array}{l}\text { Tylianakis et al. } \\
\text { (2007) }\end{array}$ \\
\hline $\begin{array}{l}\text { Bees/wasps-parasitoids on agricultural } \\
\text { land-forest gradient }\end{array}$ & Agricultural intensification & No expectation & $\begin{array}{l}\text { C higher on } \\
\text { degraded }\end{array}$ & Negative & Qualitative & No & $\begin{array}{l}\text { Tylianakis et al. } \\
\text { (2007) }\end{array}$ \\
\hline Plant-herbivores-carnivore on grasslands & Disturbance & No expectation & $\begin{array}{l}\text { C lower on } \\
\text { disturbed }\end{array}$ & Positive & Qualitative & No & Voigt et al. (2007) \\
\hline Plant-pollinator visitation web on heathlands & Restoration & Positive & C higher on ancient & Positive (?) & Qualitative & Yes (?) & Forup et al. (2008) \\
\hline $\begin{array}{l}10 \text { published Plant-pollinator webs (forest, } 2 \\
\text { insular) }\end{array}$ & Plant invasion & No expectation & No effect & None & Qualitative & Yes & Aizen et al. (2008) \\
\hline Marine food web & Disturbance/degradation & Positive & $\begin{array}{l}\text { C lower on } \\
\text { degraded }\end{array}$ & Positive & Qualitative & No & Coll et al. (2008) \\
\hline Plant-herbivores-parasitoids on forest & Plant invasion & No expectation & No effect & None & Quantitative & Yes & Heleno et al. (2009) \\
\hline Plant-pollinator-parasitoids on heathlands & Restoration & Positive & No effect & None & Quantitative & No & $\begin{array}{l}\text { Henson et al. } \\
\text { (2009) }\end{array}$ \\
\hline Organic vs convencional farms & Biodiversity loss & Negative & No effect & None & Quantitative & No (?) & $\begin{array}{l}\text { MacFadyen et al. } \\
\text { (2009) }\end{array}$ \\
\hline Plant-pollinator & Plant invasion & Negative & No effect & None & Qualitative & Yes & Vilà et al. (2009) \\
\hline Organic vs convencional farms & Biodiversity loss & Negative & $\begin{array}{l}\text { C marginally lower } \\
\text { on organic farms }\end{array}$ & Negative & Qualitative & No & $\begin{array}{l}\text { MacFadyen et al. } \\
\text { (2009) }\end{array}$ \\
\hline Plant-pollinator & Plant invasion & No change & No effect & None & Qualitative & Yes & Padrón et al. (2009) \\
\hline Plant-herbivores-parasitoids on forest & Restoration & Negative & $\begin{array}{l}\text { C marginally lower } \\
\text { on restored }\end{array}$ & None (?) & Quantitative & Yes & Heleno et al. (2010) \\
\hline
\end{tabular}


of connectance: its calculation is debatable (Cohen et al., 1993) and it is dependent on network size, sampling effort, and to the inclusion of interaction strengths (Banasek-Richter et al., 2004; Blüthgen et al., 2008), However, connectance remains the main measure of network complexity (e.g. Banasek-Richter et al., 2009; Estrada, 2007).

One of the broadly accepted generalizations involving connectance is that high connectance is a characteristic of pristine or near pristine communities that tends to protects them from secondary extinctions (Dunne et al., 2002; Thébault and Fontaine, 2010). An important corollary to this view is that highly connected communities are implicitly accepted to be "desirable" from a conservationist view point, i.e. a positive relationship between connectance and conservation value is generally assumed (Gilbert, 2009). Although the ubiquity of this relationship has been questioned (Tylianakis et al., 2010), connectance has been suggested as an important and holistic biological indicator (Gilbert, 2009) and that conservation efforts should be orientated to protect and promote highly connected communities.

We conducted a literature review to test for an empirical relationship between perceived conservation value of species interaction networks and their connectance.

\section{Methods}

We conducted a literature search for studies where connectance was compared between communities differing in their conservation status, such as due to pollution, biological invasions or habitat fragmentation. We conducted online searches for the term "connectance" on ISI Web of Knowledge, Science Direct and Google Scholar, (search conducted in June 2010).

The relative conservation value of the compared communities is case-specific and (by definition) subjective and was inferred from each study. As a general rule, communities which undergone degredation, i.e. alterations as a consequence of external environmental threats (e.g. acid rains, biological invasions, overfishing) are considered to have lower conservation value than near-pristine communities.

\section{Results and discussion}

The search yielded 287 studies of which only 20 discussed the effect on connectance of some form of ecological degradation. These 20 studies presented data for 23 systems (Table 1 ).

Only 12 studies express any a priori expectation (even if implicitly) towards the relationship between connectance and conservation value, and these cover the whole range of possible relationships (Table 1 ). Six studies (26\%) found that connectance increased with environmental degradation (a negative relationship between connectance and conservation value), seven studies (30\%) found that connectance was reduced with environmental degradation (a positive relationship), and nine studies (43\%) did not detect any relationship.

Only five studies (22\%) considered interaction frequency on the calculation of connectance and only ten studies (43\%) considered the effect of network size in the comparison of connectance between communities. While these hinder the statistical comparison of conservation values per se it is less important when only the direction of the change in connectance is compared.

The empirical finding of a positive relationship of conservation value with connectance fits the assumption that pristine communities are more complex, which protects them from environmental threats. On the other hand, a negative relationship can be predicted since connectance quantifies the average generalization of species (Dunne et al., 2004; Warren, 1994), i.e. connectance decreases when specialists are lost or generalists are gained. Both situations are likely under an ecological threat because specialists tend to face increased risk of extinction (Devictor et al., 2008), while generalists are better able to resist extinction and better able to become expand their ranges (McKinney and Lockwood, 1999). Our results suggest that there is not sufficient empirical evidence of a general relationship between ecological degradation and connectance, as might be naively expected. Instead the relationship is context-specific, which requires the development of context-specific hypotheses.

Unfortunately, a formal meta-analysis on the relationship between connectance and conservation value is not yet possible as most studies do not include replicates for their networks, and therefore no measures of data dispersal (e.g. standard deviation) can be calculated. Nevertheless our review clearly suggests that the way that ecological degradation affects connectance is highly context-specific.

\section{Conclusion}

In the face of the ongoing biodiversity crisis, we must understand the consequences of species loss for the conservation of ecosystem functions (Kremen and Hall, 2005). However, network studies often assume all nodes (i.e. species), to differ only in their ecosystem function (Thébault and Fontaine, 2010), a simplification which equally weights the conservation of all species: from critically endangered endemic species to weeds (e.g. Heleno et al., 2009). Given the conflicting empirical evidence revealed in this study, it is clear that connectance, applied on its own and interpreted simplistically, cannot be used as an indicator of conservation value, in the way that value is normally ascribed. We believe that descriptors of species interaction networks clearly have an important role to play in guiding conservation efforts and their use should be encouraged However, while ecologists are developing increasingly robust measures of network complexity and network robustness (Blüthgen, 2010), to date, such measures have not included basic considerations of species conservation value. Although this remains a heady goal, such step would largely benefit the application of ecological network theory in conservation practice.

\section{Acknowledgments}

We thank S. Pearce, L. Carvalheiro, D. Evans, R. Gibson and K. Henson for discussion on the topic and J. Memmott, J. Ramos, J. Olesen and A. Traveset for comments on the manuscript.

\section{References}

Aizen, M.A., Morales, C.L., Morales, J.M., 2008. Invasive mutualists erode native pollination webs. Plos Biol. 6 (2), e31.

Banasek-Richter, C., Cattin, M.F., Bersier, L.F., 2004. Sampling effects and the robustness of quantitative and qualitative food-web descriptors. J. Theor. Biol. 226 (1), 23-32.

Banasek-Richter, C., Bersier, L.F., Cattin, M.F., Baltensperger, R., Gabriel, J.P., Merz, Y., Ulanowicz, R.E., Tavares, A.F., Williams, D.D., De Ruiter, P.C., Winemiller, K.O., Naisbit, R.E., 2009. Complexity in quantitative food webs. Ecology 90 (6), 1470-1477.

Blüthgen, N., Fründ, J., Vásquez, D.P., Menzel, F., 2008. What do interaction networks metrics tell us about specialization and biological traits? Ecology 89 (12), 3387-3399.

Blüthgen, N., 2010. Why network analysis is often disconnected from community ecology: a critique and an ecologist's guide. Basic Appl. Ecol. 11, 185-195.

Briand, F., 1983. Environmental-control of food web structure. Ecology 64 (2), 253-263.

Charlebois, P.M., Lamberti, G.A., 1996. Invading crayfish in a Michigan stream: direct and indirect effects on periphyton and macroinvertebrates. J. N. Am. Benthol. Soc. 15 (4), 551-563.

Cohen, J.E., Beaver, R.A., Cousins, S.H., Deangelis, D.L., Goldwasser, L., Heong, K.L., Holt, R.D., Kohn, A.J., Lawton, J.H., Martinez, N., Omalley, R., Page, L.M., Patten, B.C., Pimm, S.L., Polis, G.A., Rejmanek, M., Schoener, T.W., Schoenly, K., Sprules, 
W.G., Teal, J.M., Ulanowicz, R.E., Warren, P.H., Wilbur, H.M., Yodzis, P., 1993. Improving food webs. Ecology 74 (1), 252-258.

Coll, M., Lotze, H.K., Romanuk, T.N., 2008. Structural degradation in Mediterranean Sea food webs: testing ecological hypotheses using stochastic and mass-balance modelling. Ecosystems 11 (6), 939-960.

Devictor, V., Julliard, R., Jiguet, F., 2008. Distribution of specialist and generalist species along spatial gradients of habitat disturbance and fragmentation. Oikos $117,507-514$

Duffy, J.E., Carinale, B.J., France, K.E., McIntyre, P.B., Thébault, E., Loreau, M., 2007. The functional role of biodiversity in ecosystems: incorporating trophic complexity. Ecol. Lett. 10 (6), 522-538.

Dunne, J.A., Williams, R.J., Martinez, N.D., 2002. Network structure and biodiversity loss in food webs: robustness increases with connectance. Ecol. Lett. 5 (4), 558-567.

Dunne, J.A., Williams, R.J., Martinez, N.D., 2004. Network structure and robustness of marine food webs. Mar. Ecol.-Prog. Ser. 273, 291-302.

Estrada, E., 2007. Food webs robustness to biodiversity loss: the roles of connectance, expansibility and degree distribution. J. Theor. Biol. 244 (2), 296-307.

Forup, M.L., Memmott, J., 2005. The restoration of plant-pollinator interactions in hay meadows. Restor. Ecol. 13 (2), 265-274.

Forup, M.L., Henson, K.S.E., Craze, P.G., Memmott, J., 2008. The restoration of ecological interactions: plant-pollinator networks on ancient and restored heathlands. J. Appl. Ecol. 45 (3), 742-752.

Gilbert, A.J., 2009. Connectance indicates the robustness of food webs when subjected to species loss. Ecol. Indic. 9 (1), 72-80.

Heleno, R.H., Ceia, R.S., Ramos, J.A., Memmott, J., 2009. The effect of alien plants on insect abundance and biomass: a food web approach. Conserv. Biol. 23 (2), 410-419.

Heleno, R.H., Lacerda, I., Ramos, J.A., Memmott, J., 2010. Evaluation of restoration effectiveness: community response to the removal of alien plants. Ecol. Appl. 20 (5), 1191-1203.

Henson, K.S.E., Craze, P.G., Memmott, J., 2009. The restoration of parasites, parasitoids, and pathogens to heathland communities. Ecology 90 (7), 1840-1851.

Heymans, J.J., Shannon, L.J., Jarre, A., 2004. Changes in the northern Benguela ecosystem over three decades: 1970s, 1980s, and 1990s. Ecol. Model. 172 (2-4), 175-195.

Kremen, C., Hall, G., 2005. Managing ecosystem services: what do we need to know about their ecology? Ecol. Lett. 8 (5), 468-479.

Kreutzweiser, D.P. Sutton, T.M., Back, RC Pangle, K.L. Thompson, D.G, 2004 Some ecological implications of a neem (azadirachtin) insecticide disturbance to zooplankton communities in forest pond enclosures. Aquat. Toxicol. 67 (3), 239-254.
Locke, A., Sprules, W.G., 1994. Effects of lake acidification and recovery on the stability of zooplankton food webs. Ecology 75 (2), 498-506.

MacFadyen, S., Gibson, R., Polaszek, A., Morris, R.J., Craze, P.G., Planque, R., Symondson, W.O.C., Memmott, J., 2009. Do differences in food web structure between organic and conventional farms affect the ecosystem service of pest control? Ecol. Lett. 12 (3), 229-238.

May, R., 1999. Unanswered questions in ecology. Philos. Trans. R. Soc. Lond. Ser. B: Biol. Sci. 354 (1392), 1951-1959.

May, R.M., 1973. Stability and Complexity in Model Ecossystems. Princeton University Press, Princeton.

McKinney, M.L., Lockwood, J.L., 1999. Biotic homogenization: a few winners replac ing many losers in the next mass extinction. Trends Ecol. Evol. 14 (11), 450-453.

Memmott, J., Waser, N.M., 2002. Integration of alien plants into a native flowerpollinator visitation web. Proc. R. Soc. Lond. Ser. B: Biol. Sci. 269 (1508), 2395-2399.

Millennium Ecosystem Assessment, 2005. Ecosystems and Human Well-being: A Synthesis. Millennium Ecosystem Assessment, Island Press, Washington D.C.

Padrón, B., Traveset, A., Biedenweg, T., Díaz, D., Nogales, M., Olesen, J.M., 2009. Impact of alien plant invaders on pollination networks in two archipelagos. PLoS ONE 4 (7), e6275, doi:6210.1371/journal.pone.0006275.

Pimm, S.L., 1984. The complexity and stability of ecosystems. Nature 307 (5949), 321-326.

Thébault, E., Fontaine, C., 2010. Stability of ecological communities and the architecture of mutualistic and trophic networks. Science 329, 853-856.

Townsend, C.R., Thompson, R.M., McIntosh, A.R., Kilroy, C., Edwards, E., Scarsbrook, M.R., 1998. Disturbance, resource supply, and food-web architecture in streams. Ecol. Lett. 1 (3), 200-209.

Tylianakis, J.M., Laliberté, E., Nielsen, A., Bascompte, J., 2010. Conservation of species interaction networks. Biol. Conserv. 143 (10), 2270-2279.

Tylianakis, J.M., Tscharntke, T., Lewis, O.T., 2007. Habitat modification alters the structure of tropical host-parasitoid food webs. Nature 445 (7124) 202-205.

Vilà, M., Bartomeus, I., Dietzsch, A.C., Petanidou, T., Steffan-Dewenter, I., Stout, J.C. Tscheulin, T., 2009. Invasive plant integration into native plant-pollinator networks across Europe. Proc. R. Soc. Lond. Ser. B-Biol. Sci. 276 (1674) 3887-3893.

Voigt, W., Perner, J., Jones, T.H., 2007. Using functional groups to investigate community response to environmental changes: two grassland case studies. Glob. Change Biol. 13 (8), 1710-1721.

Warren, P.H., 1994. Making connections in food webs. Trends Ecol. Evol. 9 (4) 136-141.

Woodward, G., Hildrew, A.G., 2001. Invasion of a stream food web by a new top predator. J. Anim. Ecol. 70 (2), 273-288. 